OPEN ACCESS

Edited by:

Zuben E. Sauna,

United States Food and Drug Administration, United States

Reviewed by:

Brandon DeKosky,

University of Kansas, United States

Vibha Jawa,

Merck Sharp \& Dohme Corp,

United States

*Correspondence:

Elizabeth A. Fitzpatrick efitzpat@uthsc.edu

Specialty section:

This article was submitted to Vaccines and Molecular Therapeutics, a section of the journal

Frontiers in Immunology

Received: 16 December 2019 Accepted: 04 March 2020 Published: 25 March 2020

Citation:

Fitzpatrick EA, Wang J and Strome SE (2020) Engineering of FC Multimers as

a Protein Therapy for Autoimmune

Disease. Front. Immunol. 11:496.

doi: 10.3389/fimmu.2020.00496

\section{Engineering of Fc Multimers as a Protein Therapy for Autoimmune Disease}

\author{
Elizabeth A. Fitzpatrick ${ }^{1 *}$, Jin Wang $^{2}$ and S. E. Strome ${ }^{1}$ \\ ${ }^{1}$ Department of Microbiology, Immunology and Biochemistry, College of Medicine, University of Tennessee Health Science \\ Center (UTHSC), Memphis, TN, United States, ${ }^{2}$ College of Graduate Health Sciences, University of Tennessee Health \\ Science Center, Memphis, TN, United States
}

The success of Intravenous Immunoglobulin in treating autoimmune and inflammatory processes such as immune thrombocytopenia purpura and Kawasaki disease has led to renewed interest in developing recombinant molecules capable of recapitulating these therapeutic effects. The anti-inflammatory properties of IVIG are, in part, due to the $F_{c}$ region of the IgG molecule, which interacts with activating or inhibitory Fc $\gamma$ receptors (Fc $\gamma R s$ ), the neonatal Fc Receptor, non-canonical FcRs expressed by immune cells and complement proteins. In most cases, Fc interactions with these cognate receptors are dependent upon avidity - avidity which naturally occurs when polyclonal antibodies recognize unique antigens on a given target. The functional consequences of these avid interactions include antibody dependent cell-mediated cytotoxicity, antibody dependent cell phagocytosis, degranulation, direct killing, and/or complement activation - all of which are associated with long-term immunomodulatory effects. Many of these immunologic effects can be recapitulated using recombinant or non-recombinant approaches to induce Fc multimerization, affording the potential to develop a new class of therapeutics. In this review, we discuss the history of tolerance induction by immune complexes that has led to the therapeutic development of artificial Fc bearing immune aggregates and recombinant Fc multimers. The contribution of structure, aggregation and N-glycosylation to human lgG: Fc $\gamma R$ interactions and the functional effect(s) of these interactions are reviewed. Understanding the mechanisms by which Fc multimers induce tolerance and attempts to engineer Fc multimers to target specific FcyRs and/or specific effector functions in autoimmune disorders is explored in detail.

Keywords: IVIG-intravenous immunoglobulin, Fc multimer, autoimmune, FcgR, complement

\section{INTRODUCTION}

Immunoglobulin (IVIG) is approved as a therapeutic for chronic autoimmune and inflammatory processes such as immune thrombocytopenia purpura (ITP) and Kawasaki disease, among others (1). However, IVIG is expensive to produce, has blood borne pathogen risks, toxic side effects, and because it is pooled from plasma from thousands of human donors, there is both a lack of consistency among preparations (2-5) and intermittent supply shortages. There is a critical need to develop recombinant therapeutics that reproduce the anti-inflammatory effects of IVIG. One 
of the major mechanisms by which IVIG exerts antiinflammatory properties is through the Fc domain of the IgG molecule (6). The Fc fragment has important biological effector functions that are controlled by IgG isotype, aggregation, interactions with $\mathrm{Fc} \gamma \mathrm{Rs}$ and complement components. Identifying the mechanisms by which these factors contribute to the protective effect of IVIG is critical to the development of novel IVIG replacement therapies.

\section{STRUCTURE OF IgG AND FC FRAGMENT}

The immunoglobulin molecule (IgG) consists of two identical light chains and two identical heavy chains that can be divided into two proteolytic fragments; the antigen-binding fragment (Fab) and the $\mathrm{Fc}$ fragment consisting of the $\mathrm{C}_{\mathrm{H}} 2$ and $\mathrm{C}_{\mathrm{H}} 3$ regions of the heavy chain (Figure 1). The Fc fragment mediates effector functions of IgG such as antibody-dependent cellular cytotoxicity (ADCC) or complement-dependent cytotoxicity (CDC), through the binding of soluble and cell-surface proteins to distinct residues within the $\mathrm{C}_{\mathrm{H}} 2$ and $\mathrm{C}_{\mathrm{H}} 3$ domain. The classical Fc $\gamma$ Rs bind to residues near the hinge region in $\mathrm{C}_{\mathrm{H}} 2$ and have a partial overlap with the site of $\mathrm{C} 1 \mathrm{q}$ binding (12-17). Additional Fc binding proteins such as the neonatal $F c$ receptor $(F c R n)$ and Tripartite motif-containing 21 (TRIM21) bind to residues within both the $\mathrm{C}_{\mathrm{H}} 2$ and $\mathrm{C}_{\mathrm{H}} 3$ region $(18,19)$. There is considerable heterogeneity in Fc glycosylation and the amino acid sequences of hinge regions between different IgG isotypes, all of which affect the binding affinity of IgGs to Fc $\gamma$ R's and consequent effector function.

\section{Glycosylation}

Within the $\mathrm{C}_{\mathrm{H}} 2$ portion of the $\mathrm{Fc}$ fragment is a conserved $\mathrm{N}$ linked glycosylation site at Asn-297, which consists of a mannose and $\mathrm{N}$-acetylglucosamine (GlcNAc) core structure and varying glycan species including fucose and galactose that may have added sialic acid residues (20). The N-linked glycan, N297, is necessary for stabilization of the Fc fragment and binding to Fc $\gamma$ Rs and its removal abolishes Fc effector functions (7). Changes in the patterns of $\mathrm{N}$-linked glycosylation are recognized to affect the biologic properties of antibodies (21-24). Particularly germane to this review, are studies suggesting that $\alpha$ 2,6 sialylated Fc fragments are responsible for all of the anti-inflammatory properties of IVIG through engagement of the C-type lectin DCSIGN (25). In support of this theory, several reports now suggest that the degree of circulating sialylated antibodies correlates with the activity of specific autoimmune and inflammatory conditions in humans (26-28). However, a large cohort of other studies clearly refute the import of $\alpha 2,6$ sialylated Fc fragments in

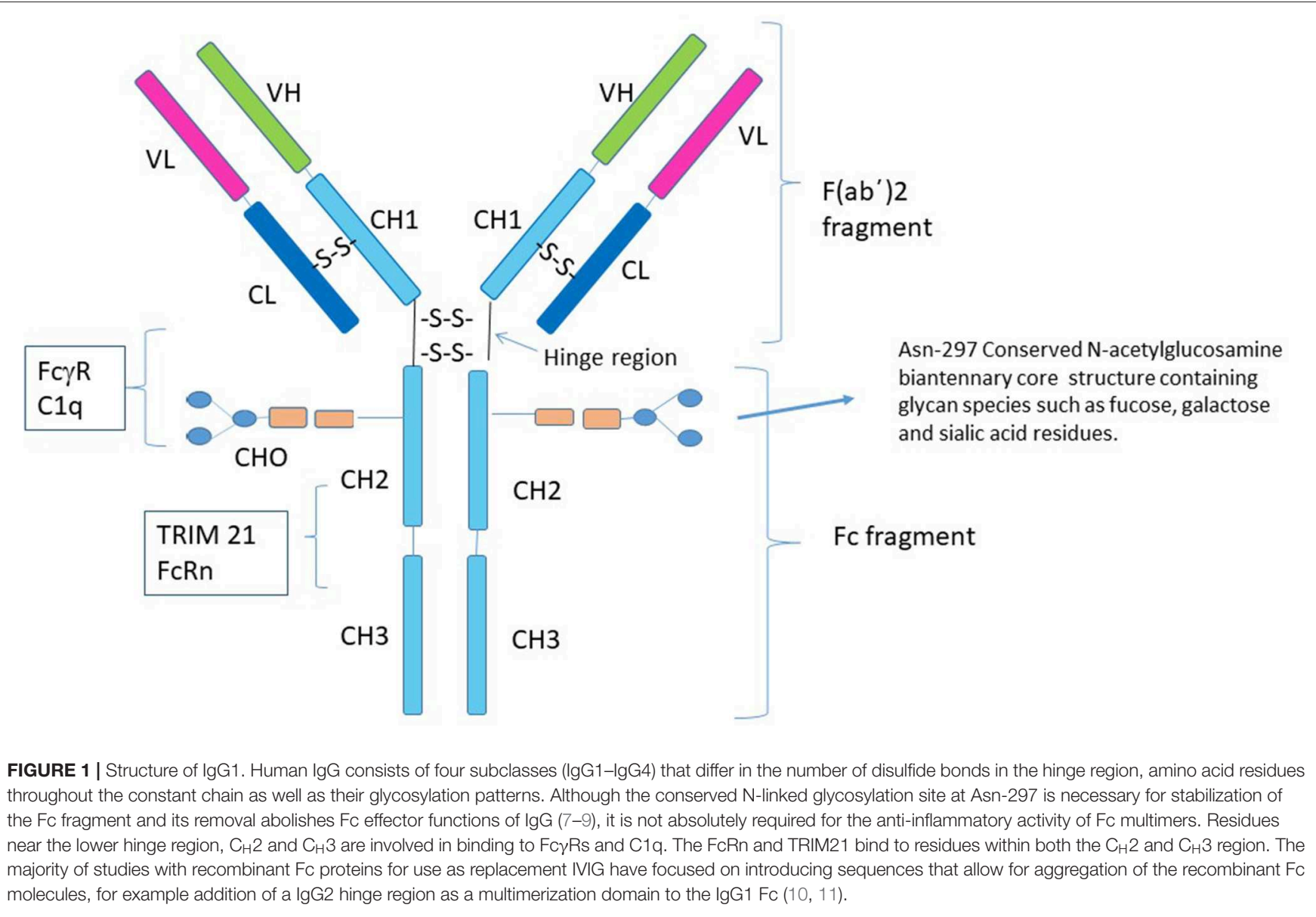


the function of IVIG mediated tolerance, showing that these fragments do not bind DC-SIGN and that removal of $\alpha 2,6$ sialylated Fcs does not impact the anti-inflammatory properties of IVIG (29-32). As such, the role of $\alpha 2,6$ sialylated Fcs in the tolerogenic properties of IVIG remains the subject of ongoing scientific debate.

\section{$F_{\gamma} \gamma R^{\prime} S$}

The classical Fc $\gamma$ Rs are cell membrane associated proteins expressed on a variety of immune cells such as macrophages, dendritic cells (DCs), natural killer (NK) cells, neutrophils, and $B$ cells. In humans, there are three types of Fc $\gamma$ Rs: hFc $\gamma \mathrm{RI}$ /CD64, hFc $\gamma \mathrm{RII} / \mathrm{CD} 32$, and $\mathrm{hFc} \gamma \mathrm{RIII} / \mathrm{CD} 16$, that are grouped based on structural homology (Figure 2). The Fc $\gamma$ RII and Fc $\gamma$ RIII subfamilies are further subdivided into Fc $\gamma$ RIIa (CD32a), Fc $\gamma$ RIIb (CD32b) and Fc $\gamma$ RIIc (CD32c) and Fc $\gamma$ RIIIa (CD16a) and Fc $\gamma$ RIIIb (CD16b). From a conceptual perspective, the functional differences in these individual $\mathrm{Fc} \gamma \mathrm{Rs}$ are based on their different affinities for the naturally occurring Fc fragment, their inducibility, their patterns of cellular expression, their ability to mediate internalization of immune complexes and the pathways through which they signal [reviewed in $(33,35,36)]$.

\section{OTHER IgG FC BINDING LIGANDS}

Complementing the classical Fc $\gamma$ Rs, are a relatively diverse set of non-canonical Fc $\gamma$ Rs which contribute to the functions of antibody homodimers and $\mathrm{Fc}$ bearing ICs. For instance, the neonatal $\mathrm{FcR}(\mathrm{FcRn})$ is an MHC Class I-like molecule that is associated with $\beta 2$-microglobulin and is responsible for IgG halflife as well as other functions such as transferring IgG from the mother across the placenta to the fetus [reviewed in (37-43)]. Similarly, intracellular receptor Tripartite motif-containing 21 (TRIM21) appears to play a role in neutralization of antibody decorated pathogens $(19,44-48)]$. Finally, FcRL5 is a cell surface protein expressed on B cells and able to bind all IgG subclasses $(49,50)$. It has two ITIM and two ITAM motifs within its cytoplasmic domain suggesting that it can induce inhibitory or activating signals (51).

In addition to these cell-based receptors, soluble proteins such as complement can also engage multimerized/aggregated Fc. For

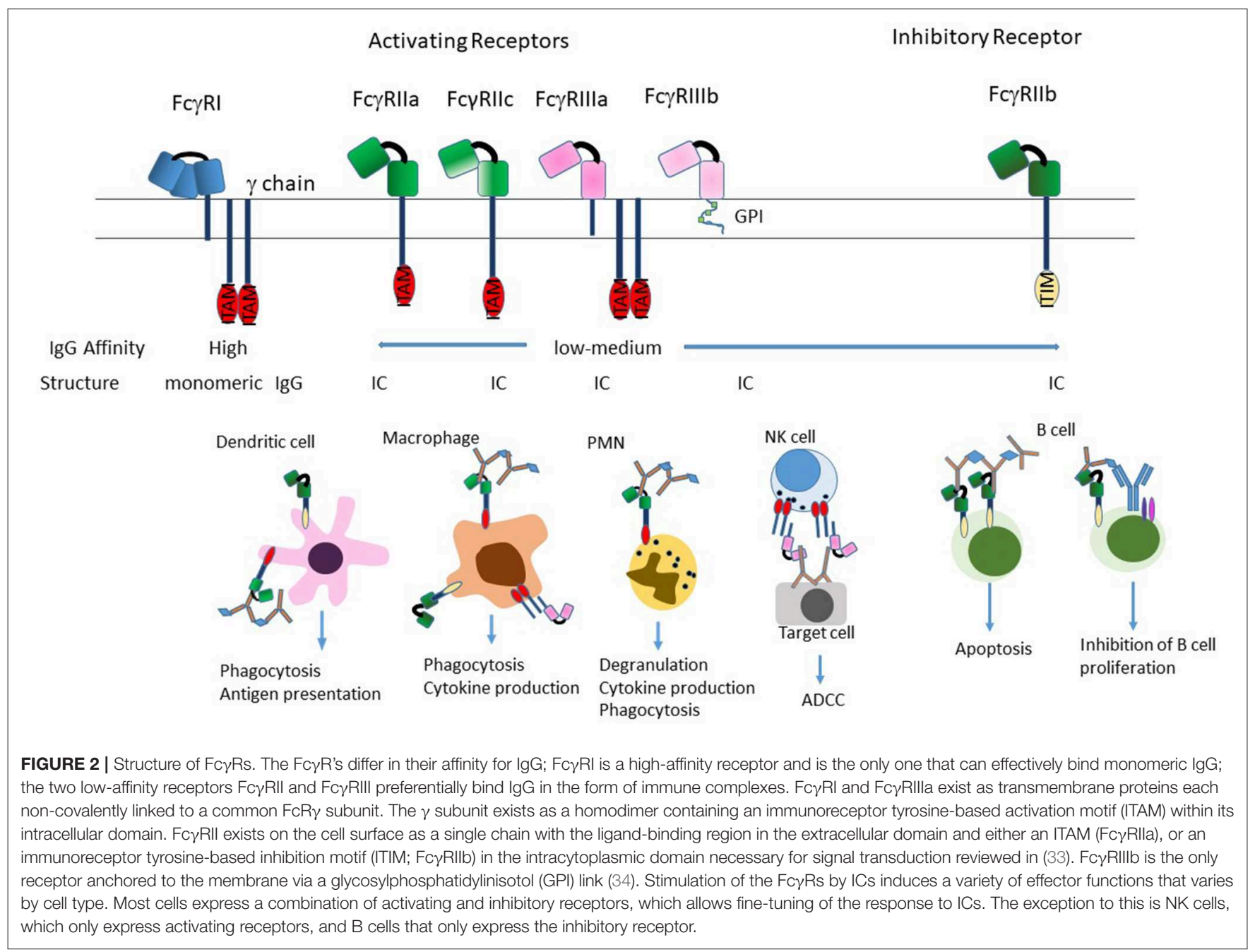


instance, $\mathrm{Clq}$ is a hexamer composed of two trimers containing an $\mathrm{A}, \mathrm{B}$, and $\mathrm{C}$ chain each with collagen-like stalk portions and globular heads resulting in the characteristic "bundle of six tulips" (52). Binding of $\mathrm{Clq}$ by ICs results in the engagement of $\mathrm{C} 1 \mathrm{r}$ and $\mathrm{C} 1 \mathrm{~s}$ and subsequently activation of the classical complement cascade. (53-56). Importantly, and as discussed in later sections, unlike the scenario in which $\mathrm{Clq}$ binds an antibody decorated cell and induces C5b-9 pore formation, IC mediated activation of the classical cascade may occur away from the cell surface, resulting in a poorly defined series of immunomodulatory effects.

\section{CONCEPTUAL BASIS FOR THE DEVELOPMENT OF FC MULTIMERS TO INDUCE TOLERANCE}

The conceptual basis for developing Fc multimers as a tolerogenic therapy is based on the anti-inflammatory role of the $\mathrm{Fc}$ fragment in IVIG. However, there is historical evidence that ICs possess anti-inflammatory properties in addition to their well-described pro-inflammatory effects. Careful observational studies by Flexner in 1906, introduced the concept of tumor enhancement, where heated tumor emulsions administered 10 days prior to tumor implantation, augmented the growth of subsequent tumor implants in rats (57). Although any role of IgG in these earlier studies is unclear, the phenomenon of tumor enhancement has been observed following passive transfer of anti-serum prior to tumor inoculation (58). Studies by Kaliss et al. (59-61) demonstrated that transfer of serum from animals that had rejected a primary tumor to naïve animals potentiated subsequent tumor growth. The enhancing activity was found to be associated with the gamma-globulin fraction (62). Many mechanisms have been put forward to explain tumor enhancement by IgG including masking of tumor antigens by antibody $(61,63)$ or a shift in the Th1 to Th2 cytokine response favoring tumor growth (64), however $\mathrm{Fc} \gamma \mathrm{R}$ dependent mechanisms such as inhibition of ADCC may also explain this phenomenon (63).

Clinical evidence supporting the potential therapeutic role of ICs in preventing disease is derived from the observation that treatment of ITP patients with anti-D antibodies results in an increase in platelet counts (65-67). The fact that treatment efficacy is dependent on patients being $\mathrm{Rh}^{+}$, suggests that these antibodies function by presenting aggregated Fc on the surface of $\mathrm{Rh}^{+}$cells $(68,69)$. The observation that it requires at least $48 \mathrm{~h}$ for patients to respond-longer than the time necessary for saturation of the $\mathrm{FcR}$ - highlights the immunomodulatory nature of these effects (68).

The conceptual underpinnings for the idea that Fc multimers have anti-inflammatory properties are also founded on examples of naturally occurring multimeric Fc like proteins with tolerogenic properties. For instance, the short pentraxins are evolutionarily conserved precursors of existing antibodies, whose pentameric structure allows them to engage the low affinity Fc $\gamma$ Rs and complement (70). While initially recognized to bind and regulate the immune response to specific pathogens and apoptotic cells, recent data suggest that these proteins also have profound anti-inflammatory activity [reviewed in (71)]. For example, serum amyloid P (SAP) inhibits many of the pro-inflammatory components of neutrophil function and also prevents the conversion of monocytes into fibrocytes, potentially mitigating fibrosis (72). Collectively, these studies provide both the historical context and biologic basis for employing recombinant multimerized Fc compounds to mimic the tolerogenic properties of the Fc portion of aggregates in IVIG. In addition, they force a re-evaluation of the concept that ICs only induce inflammation-suggesting that in some cases they may be induced in response to pro-inflammatory events as a means to restore immune homeostasis.

\section{DEVELOPMENT OF RECOMBINANT FC MULTIMERS AS THERAPEUTICS}

Based on the supposition that artificial Fc bearing immune complexes might induce tolerance, our laboratory in collaboration with Gliknik ${ }^{\circledR}$, followed by several other groups, sought to develop fully recombinant IgG multimers for both clinical translation and mechanistic experiments. Specifically, we developed linked multimerization domain (MD) sequences from the hinge region of human IgG2 or the isoleucine zipper (ILZ) to the carboxy or amino termini of the murine IgG2a. The resultant stradomers $^{\mathrm{TM}}$ contained both homodimers and highly ordered multimers of the Fc homodimers. One of these stradomers ${ }^{\mathrm{TM}}$, bearing the IgG2 hinge (M045), effectively binds to Fc $\gamma$ RI, Fc $\gamma$ RIIb and Fc $\gamma$ RIII with significantly lower Kd values than control IgG2a Fc, inhibits the development of collagen-induced arthritis (CIA) and protects against platelet destruction. The fact that most of the therapeutic activity of this drug resides in the multimeric fraction, highlights the relative importance of avidity, rather than affinity, for its biologic activity (10). Collectively, these data provided the first evidence that recombinant immune complexes could induce tolerance.

Subsequent studies confirmed and extended these findings, demonstrating that stradomers $^{\mathrm{TM}}$ can effectively inhibit development of experimental autoimmune neuritis model (73) and experimental autoimmune myasthenia gravis (EAMG) (74). Importantly, the studies in EAMG provided significant mechanistic insights, showing that daily administration of stradomers $^{\mathrm{TM}}$ reduces Acetylcholine Receptor (AchR) antibody levels, decreases antigen specific $\mathrm{T}$ cell proliferation, downmodulates both B cell and DC maturation markers, up-regulates inhibitory Fc $\gamma$ RIIb expression, and is associated with an increase in both Tregs and immunosuppressive cytokines such as IL-10 and IL-4 (74). We are attempting to distinguish the relative importance of the FcRs and complement on these biologics by employing complement preferential stradomers ${ }^{\mathrm{TM}}$ in vitro and in vivo $(11,75)$.

In order to translate our preclinical findings, we developed a human analog of these drugs, GL-2045, by joining the human IgG2 hinge region to the C-terminus of the human IgG1 Fc fragment (76). GL-2045 avidly binds human Fc $\gamma$ RI, Fc $\gamma$ RIIa, Fc $\gamma$ RIIb and Fc $\gamma$ RIIIa as well as to rat, mouse and cynomolgus monkey Fc $\gamma$ Rs, protects mice from platelet loss in a rodent ITP 
model and inhibits CIA. Of perhaps greater import, GL-2045 infusion into healthy cynomolgus monkeys is well-tolerated and induces transient and highly ordered increases in IL-1RA and IL10 as well as a temporary suppression of IL-8, without significant induction of proinflammatory cytokines (76).

Following our initial studies, several other groups reported that recombinant Fc multimers can ameliorate autoimmune disease, suggesting that some of the properties of these multimers might be generalizable. For instance, Mekhaiel et al. (77) generated a hexameric $\mathrm{Fc}$ by joining the Fc portion of human IgG1 to an 18 amino acid sequence from the C-termini of the IgM $\mu$-tailpiece with a leucine 309 to a cysteine mutation (78, 79). This compound exhibits greater affinity for the Fc $\gamma$ Rs than IVIG and upon internalization, is associated with preferential degradation of the activating $\mathrm{Fc} \gamma \mathrm{Rs}$ and protects mice from platelet loss for up to 3 days after dosing (80). Studies with analogous compounds demonstrate clinical efficacy in both CIA and in the $\mathrm{K} / \mathrm{BxN}$ model of chronic arthritis (81). These data lend credence to the idea that structurally distinct ICs can have anti-inflammatory properties.

In order to better understand the relationship between IgG1 $\mathrm{Fc}$ valency/ structure on $\mathrm{Fc} \gamma \mathrm{R}$ engagement/function, Ortiz et al. (82) evaluated the function of Fc multimers with increasing valency and observed that structures containing 2 and $3 \mathrm{Fc}$ domains avidly bind Fc $\gamma$ Rs, but unlike molecules containing 5 Fc domains, do not induce Syk phosphorylation or a calcium flux in macrophages. In addition, the larger structures are internalized along with Fc $\gamma$ RII, whereas the smaller structures remain on the cell surface co-localized with Fc $\gamma$ RII. Subsequent studies showed that the trivalent $\mathrm{Fc}(\mathrm{Fc} 3 \mathrm{Y})$ competitively inhibits several IC mediated $\mathrm{F} c \gamma \mathrm{R}$ functions and protects mice from ITP (82). Importantly, given the valency of Fc3Y, the extent to which it can immunomodulate the complement cascade is uncertain. Collectively, these data support the idea that Fc bearing immune complexes may serve as a protective mechanism against inflammation and, as a corollary, that recombinant Fc multimers might have therapeutic value for the treatment of autoimmunity.

\section{ANTI-INFLAMMATORY MECHANISMS OF RECOMBINANT FC MULTIMERS}

The development of Fc multimers as a replacement for IVIG is a significant therapeutic advance. Importantly, like IVIG, these molecules likely function by numerous overlapping mechanisms, influenced by the number of IgG Fc domains presented to ligands, the IgG isotype, and the conformational flexibility of the aggregate or Fc multimers $(76,77,82)$. Moreover, the relative activity is likely dependent upon the specific underlying disease, the state of maturation of immune cells in that disease and other prior treatments.

From a conceptual perspective, it is our hypothesis that recombinant ICs require and/or benefit from immune activation as a necessary precursor for the induction of tolerance. Specifically, given that multiple redundant immunologic pathways are in place to restore immune homeostasis, it is highly possible, if not likely, that the initial inflammatory response induced by recombinant Fc multimers induces a compensatory response that restores immune homeostasis. In this regard, it is noteworthy that IVIG can be associated with initial fever, chills, headache, and transient release of pro-inflammatory cytokines $(83,84)$ and that hypotension with IVIG administration is related to the rate of infusion of aggregates (85). It is possible that patients receiving IVIG who experience these initial proinflammatory effects are the most likely to be subsequently induced into tolerance by the Fc aggregates in IVIG. While this hypothesis remains to be validated, it is conceptually helpful in understanding the potential links between the diverse immunologic alterations mediated by these drug candidates.

\section{Biologic Decoys and Fc $\gamma$ R Blockade}

Immune complexes are associated with the development of autoimmune disease and resultant tissue damage. Because naturally occurring ICs are commonly generated around a pathogen or other type of foreign protein, it is difficult to separate the biologic effects of IC: FcR and/or complement engagement from those mediated by the target protein. Using ICs generated around single stranded DNA or RNA (ssDNA/RNA) as an example, the Fc:FcR interactions allow ssDNA/RNA access into the cell where they can drive TLR-mediated inflammation. Lacking ssDNA/RNA, recombinant Fc multimers competitively inhibit natural ICs from FcR engagement $(76,80,86)$, preventing subsequent engagement of intracellular TLRs and potentially inducing other active inhibitory functions as a result of FcR stimulation in a non-inflammatory milieu.

Additionally, Fc $\gamma$ R's efficiently internalize ICs, which allows for processing and presentation of antigenic peptides to $\mathrm{T}$ cells, further amplifying an immune response. The lack of "core" antigen in the Fc multimer preparations is likely key to the ability of the multimers to block Fc $\gamma$ Rs without inducing further inflammation.

\section{FcRn Blocking}

The FcRn has a documented role in antibody-mediated autoimmunity. Indeed, FcRn deficient mice are protected from serum transfer-induced arthritis (87). Doses of IVIG that resulted in saturation of the FcRn inhibited development of arthritis in mice lacking the inhibitory FcyRIIb (87). The FcRn plays a critical role in maintaining the plasma concentration of IgG such that high concentrations result in increased IgG clearance (88-91). Infusion of high dose IVIG results in a reduction of circulating autoantibody, which may be due in part to saturation of the FcRn and enhanced IgG catabolism (92-95), although it is likely other mechanisms such as the Fc $\gamma$ RIIb engagement also play a role (96). It is likely that Fc multimer binding to FcRn may competitively inhibit engagement of circulating antibodiespathogenic and otherwise-resulting in lysosomal degradation and non-specific decreases in antibody half-life. While many of the recombinant $\mathrm{Fc}$ multimers and hexamers bind FcRn in vitro, further studies are required to accurately characterize the role of the FcRn in mediating their anti-inflammatory activity. 


\section{Stimulation of the Fc $\gamma$ RIllb Inhibitory Receptor}

The Fc $\gamma$ RIIb inhibitory receptor is the only Fc $\gamma R$ expressed by $B$ cells and crosslinking of the B cell receptor (BcR) and Fc $\gamma$ RIIb suppresses $B$ cell proliferation and activation $(97,98)$. In contrast, ligation of Fc $\gamma$ RIIb alone may induce B cell apoptosis $(99,100)$. In addition to directly stimulating the inhibitory receptor on $\mathrm{B}$ cells, ICs and IVIG also induce its expression on both B cells and myeloid cells $(25,101,102)$. Myeloid cells express both inhibitory and activating receptors and the ratio of inhibitory to activating receptor stimulation will dictate the outcome of signaling. Therefore, IVIG or Fc multimer induced Fc $\gamma$ RIIb upregulation may favor inhibitory signaling pathways over the activating pathways.

\section{Stimulation of Activating Fc $\gamma$ Rs}

The suppressive effects of IVIG (and subsequently Fc multimers) may also be mediated by stimulating the activating receptors. For example, Park-Min et al. (103) demonstrated that IVIG suppresses IFN $\gamma$ mediated phosphorylation of Stat1 and IFN $\gamma$ dependent gene expression in macrophages in vitro. In vivo, IVIG treatment of mice infected with Listeria monocytogenes results in increased bacterial burden and decreases expression of IFN $\gamma$-dependent genes IP-10 and MIG. This effect is Fc $\gamma$ RIII dependent, as ICs do not inhibit IFN $\gamma$ signaling in B cells (which only express Fc $\gamma$ RIIb), inhibit signaling in NK cells and DCs that express Fc $\gamma$ RIII, but fail to inhibit signaling in macrophages deficient in Fc $\gamma$ RIII (103).

Stimulation of activating receptors may also modulate the production of anti- and pro-inflammatory cytokines. For instance, ICs induce the production of anti-inflammatory cytokines such as IL-10 (104) and suppress IL-12 production (105, 106). Ligation of the $\mathrm{Fc} \gamma \mathrm{R}$ on macrophages during stimulation with LPS results in a decrease in IL-12 production and an increase in IL-10 compared to LPS stimulated controls, whereas other cytokines remain unchanged (106). The inhibition of IL-12 production is not due to the expression of IL-10 as IL-10 $-/-$ macrophages also exhibit decreased IL-12 production following $\mathrm{F}_{\mathrm{C} \gamma \mathrm{R}}$ ligation and LPS stimulation. Taken together, these studies suggest that stimulation of the activating receptors by IVIG or Fc multimers, in the absence of pro-inflammatory signals, may result in induction of tolerance.

\section{Expansion of Regulatory T Cells}

Patients undergoing IVIG treatment exhibit an expansion in Tregs which may contribute to its therapeutic effects (107109). Fc multimers are recognized to cause similar increases in Tregs, with both GL-2045 and IVIG inducing Treg expansion in the EAMG model (74). An intriguing mechanism by which IVIG (and Fc multimers) may induce Tregs is the presence of highly conserved Tregitopes in the $\mathrm{C}_{\mathrm{H}} 2$ domain of the Fc fragment of human IgG (110). Upon uptake by antigen presenting cells, Tregitopes bind with high affinity to HLA molecules and cause the activation and expansion of Treg cells (111). Additional potential mechanisms for IC mediated Treg expansion include the induction of tolerogenic DCs (112-114). For instance, Trinith et al. (115) demonstrated that in vitro,
IVIG pre-treatment of DCs results in the differentiation and expansion of Tregs that is dependent on COX-2 induced $\mathrm{PGE}_{2}$ production (115). Collectively, these data suggest that IVIG and ICs have the potential to induce Tregs through multiple independent pathways.

\section{Complement Engagement}

While the complement cascade has historically been viewed as pro-inflammatory-with the generation of "anaphylatoxins" such as $\mathrm{C} 3 \mathrm{a}$, more recent studies suggest that it be considered as immunomodulatory (116-118), with the ability to induce long-term tolerance following activation. For example, following cleavage, unbound $\mathrm{C} 3 \mathrm{~b}$ is very rapidly converted into $\mathrm{iC} 3 \mathrm{~b}$; iC3b is capable of binding CR3 on dendritic cells and inducing long-term tolerance (119-121). Sohn et al. (117) demonstrated that $\mathrm{iC} 3 \mathrm{~b}$ binds to CR3 and modulates IL- 10 and TGF- $\beta 2$, preventing delayed type hypersensitivity (DTH) in a rat ocular DTH model. The fact that stradomers ${ }^{\mathrm{TM}}$ that preferentially bind complement (e.g. G211 and likely others) effectively induce iC 3b, provides a strong associative link between the generation of this and potentially other anti-inflammatory complement associated molecules and Fc multimer mediated tolerance (Figure 3) (11).

Similarly, indirect evidence suggests that Fc multimers interact with specific regulatory proteins to define the extent of complement activation. For instance, in human serum, G211 and others, mediate cleavage of C4 and to a lesser degree C3, but not significant amounts of $\mathrm{C} 5$, as evidenced by the generation of $\mathrm{C} 4 \mathrm{a}$, C3a, and the absence of C5a $(11,75)$. These effects are abrogated in Factor $\mathrm{H}$ deficient sera, suggesting that GL-211 potentiates factor $\mathrm{H}$ and/or co-factor I, limiting the generation of C5b-9 and associated cell death.

The classical arm of the complement cascade is generally activated on the cell surface as a result of antibody opsonization. Such activation mediates direct cell lysis through C5b-9 pore formation. In addition, these complement split products; decorating the cell surface, function as biologic bridges to engage complement receptors on other cells types. In contrast, hexameric $\mathrm{Clq}$ binding to IVIG or to recombinant Fc multimers, induces formation of $\mathrm{C} 4$ protease and cleavage of $\mathrm{C} 4$ away from the cell surface. C3 convertase is formed in solution, away from the cell surface, with cleavage of $\mathrm{C} 3$ to $\mathrm{C} 3 \mathrm{a}$ and $\mathrm{C} 3 \mathrm{~b}$ which immediately degrades in solution to iC $3 \mathrm{~b}$. These drugs thereby sequester complement substrates and competitively inhibit their ability to perform other biologic functions (75). Importantly, while this activation may result in soluble C5b-9 formation in vivo, soluble C5b-9 is not pore-forming, is not cell-bound, and is not associated with Complement Dependent Cytotoxicity (CDC). Indeed, the exact biologic functions of non-membrane bound C5b-9 remain unclear and may differ from the biology of cell-bound complement activation.

Finally, the act of binding of $\mathrm{Clq}$ and other complement products to aggregated immunoglobulins or to multimerized Fcs, alters both the ability of these compounds to engage FcRs and the C1q-mediated trafficking of ICs to liver and spleen. C1qopsonized ICs bind CR1-located on RBCs in humans and on platelets in mice-where they are then preferentially transported to the spleen (122). When ICs are bound to C3b, they have a 


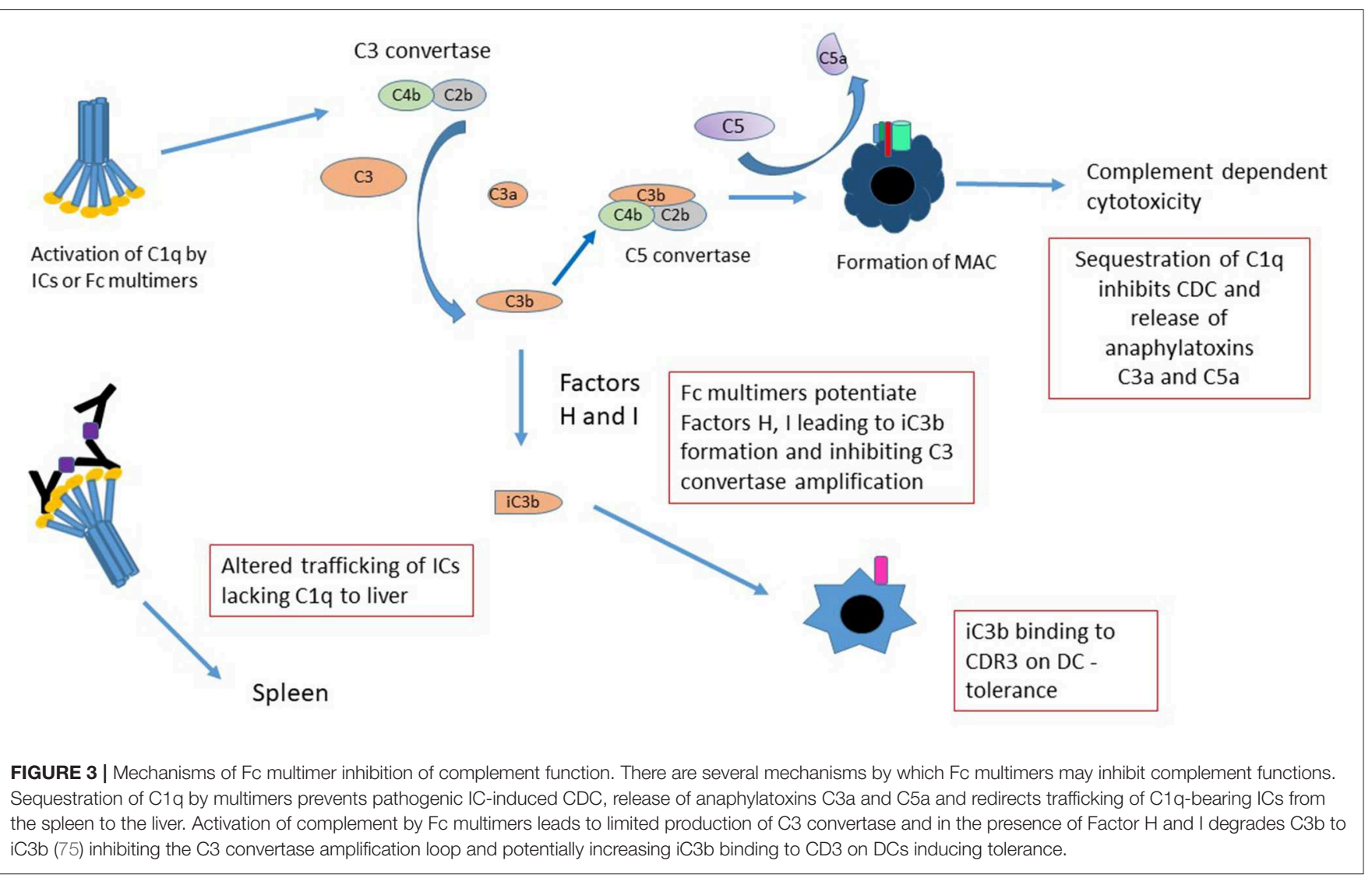

limited ability to engage $\mathrm{Fc} \gamma \mathrm{Rs}$, likely because of the partially overlapping binding sites between these moieties $(123,124)$. In the absence of C1q and/or in instances where the multimers have valency insufficient for $\mathrm{C1q}$ binding, they bypass the spleen and are preferentially transported to the liver (125). How/whether the changes in binding and trafficking mediated by complement engagement of Fc multimers alters their biology is an important subject for future study.

\section{PRO-VS. ANTI-INFLAMMATORY EFFECTS OF IMMUNE COMPLEXES: A RESOLVABLE PARADOX?}

Immune complexes can have pro-inflammatory activity-activity which may be conveniently classified in substrate dependent and substrate independent effects. Substrate dependent inflammation is induced by the partnership between $\mathrm{FcR} /$ complement engagement and the nidus of the IC. For example, in the case of ICs based on RNA viral substrates, FcR engagement may facilitate trafficking to intracellular TLR7, with resultant inflammation $(126,127)$. In contrast, substrate independent effects are induced independent of antigen, resulting from binding to the activating FcRs/complement with potential cytokine production, degranulation, cytotoxicity and/or complement activation [reviewed in (128)]. Because recombinant Fc multimers can engage FcRs and select complement fragments in the absence of an "antigenic core" they, by definition, competitively inhibit substrate dependent, Fc mediated inflammation, while promoting substrate independent inflammation in a valency dependent fashion. The degree to which such substrate independent inflammation is required for the generation of tolerance is the subject of ongoing investigation.

\section{Alternative Therapeutic Strategies for Targeting Fc $\gamma$ Rs}

To our knowledge, there are no clinically relevant chemical based strategies to engineer Fc multimers, However, as an alternative to recombinant Fc multimers, investigators are employing antibodies to target specific FcRs with therapeutic intent. For instance, several groups have generated humanized monoclonal antibodies directed against the inhibitory Fc $\gamma$ RIIb $(129,130)$ as well as the activating receptors Fc $\gamma$ RI (131) and Fc $\gamma$ RIIIa $(132,133)$ in an attempt to modulate disease activity. In addition, ongoing clinical trials are evaluating the potential of antibodies targeting the FcRn to reduce systemic antibody half-life and the absolute quantity of circulating antibodies $(134,135)$. These studies will likely define the precise roles of specific Fc receptors in different disease states.

\section{ANTIBODIES AS CONTROLS}

While not the primary focus of this manuscript, the creation of recombinant Fc multimers highlights biologic principles that must be considered when using non-specific IgG as controls 
for antibody-based studies. Specifically, binding of multiple antibodies to their cognate targets on the surface of a cell, pathogen or other molecule enables their associated Fc fragments to engage low and intermediate Fc receptors and complement. Importantly, this engagement occurs at the site dictated by the location of the epitope recognized by the Fab. In contrast, because isotype specific antibody controls lack the ability to engage epitopes they will have a different distribution within the patient/animal as the experimental antibody and not engage similar Fc receptors or cell types as the experimental antibody. In addition, the IgG isotype controls will not form IC and therefore will likely engage higher affinity receptors rather than the low affinity Fc receptors engaged by ICs. These differences suggest that the isotype control antibody will lack the ability to induce correlate Fc functions to the experimental antibody. As such, IgG isotypes are probably not appropriate controls for antibody-based studies that employ functional Fc domains.

\section{CLOSING THOUGHTS AND FUTURE DIRECTIONS}

The development of recombinant Fc multimers as treatments for autoimmune and inflammatory conditions provides an opportunity for the scientific community to reconsider the

\section{REFERENCES}

1. Imbach P, Dapuzzo V, Hirt A, Rossi E, Vest M, Barandun S, et al. Highdose intravenous gamma-globulin for idiopathic thrombocytopenic purpura in childhood. Lancet. (1981) 1:1228-31. doi: 10.1016/S0140-6736(81) 92400-4

2. Gelfand EW. Intravenous immune globulin in autoimmune and inflammatory diseases. N Engl J Med. (2012) 367:2015-25. doi: 10.1056/NEJMra1009433

3. Orange JS, Hossny EM, Weiler CR, Ballow M, Berger M, Bonilla FA, et al. Use of intravenous immunoglobulin in human disease: a review of evidence by members of the Primary Immunodeficiency Committee of the American Academy of Allergy, Asthma and Immunology. J Allergy Clin Immunol. (2006) 117:S525-53. doi: 10.1016/j.jaci.2006.01.015

4. Spath PJ, Granata G, La Marra F, Kuijpers TW, Quinti I. On the dark side of therapies with immunoglobulin concentrates: the adverse events. Front Immunol. (2015) 6:11. doi: 10.3389/fimmu.2015.00011

5. Nimmerjahn F, Ravetch JV. Anti-inflammatory actions of intravenous immunoglobulin. Annu Rev Immunol. (2008) 26:513-33. doi: 10.1146/annurev.immunol.26.021607.090232

6. Debre M, Bonnet MC, Fridman WH, Carosella E, Philippe N, Reinert $\mathrm{P}$, et al. Infusion of $\mathrm{Fc}$ gamma fragments for treatment of children with acute immune thrombocytopenic purpura. Lancet. (1993) 342:945-9. doi: 10.1016/0140-6736(93)92000-J

7. Walker MR, Woof JM, Bruggemann M, Jefferis R, Burton DR. Interaction of human IgG chimeric antibodies with the human FcRI and FcRII receptors: requirements for antibody-mediated host cell-target cell interaction. Mol Immunol. (1989) 26:403-11. doi: 10.1016/0161-5890(89)90129-6

8. Nesspor TC, Raju TS, Chin CN, Vafa O, Brezski RJ. Avidity confers FcgammaR binding and immune effector function to aglycosylated immunoglobulin G1. J Mol Recognit. (2012) 25:147-54. doi: $10.1002 / \mathrm{jmr} .2155$

9. Tao MH, Morrison SL. Studies of aglycosylated chimeric mouse-human IgG. Role of carbohydrate in the structure and effector functions mediated by the human IgG constant region. J Immunol. (1989) 143:2595-601. role of ICs in inflammation. Specifically, the data that ICs induce tolerance should prompt consideration of how/if fully competent monoclonal antibodies used for treatment of cancer and autoimmunity, may paradoxically mediate tolerogenic effects when decorating the target cell surface. Similarly, taken in concert, these data raise the possibility that the initial characterizations of ICs as pathogenic were perhaps oversimplified and that, in fact, the function of naturally occurring ICs are largely dependent on their antigenic core. Building on this theme, is it also possible, that some ICs are necessary sequelae of inflammatory events and that, under specific conditions, they play an important role in restoring immune homeostasis. Existing recombinant ICs, in combination with development of more specific agents-through altered $\mathrm{N}$-glycosylation, sequence modifications, and valency specific selection-will help the scientific community address these basic questions that are fundamental to our understanding of inflammation.

\section{AUTHOR CONTRIBUTIONS}

EF, JW, and SS wrote sections of the manuscript. EF revised and edited the final document and generated figures. SS contributed critical input to revisions.

10. Jain A, Olsen HS, Vyzasatya R, Burch E, Sakoda Y, Merigeon EY, et al. Fully recombinant IgG2a Fc multimers (stradomers) effectively treat collageninduced arthritis and prevent idiopathic thrombocytopenic purpura in mice. Arthritis Res Ther. (2012) 14:R192. doi: 10.1186/ar4024

11. Sun H, Olsen HS, Merigeon EY, So E, Burch E, Kinsey S, et al. Recombinant human IgG1 based Fc multimers, with limited FcR binding capacity, can effectively inhibit complement-mediated disease. J Autoimmun. (2017) 84:97-108. doi: 10.1016/j.jaut.2017.08.004

12. Sarmay G, Lund J, Rozsnyay Z, Gergely J, Jefferis R. Mapping and comparison of the interaction sites on the $\mathrm{FC}$ region of $\mathrm{IgG}$ responsible for triggering antibody dependent cellular cytotoxicity (ADCC) through different types of human Fc gamma receptor. Mol Immunol. (1992) 29:633-9. doi: 10.1016/0161-5890(92)90200-H

13. Jefferis $R$, Lund $J$. Interaction sites on human IgG-Fc for FcgammaR: current models. Immunol Lett. (2002) 82:57-65. doi: 10.1016/S0165-2478(02)00019-6

14. Shields RL, Namenuk AK, Hong K, Meng YG, Rae J, Briggs J, et al. High resolution mapping of the binding site on human IgG1 for Fcgamma RI. Fcgamma RII, Fcgamma RIII, and FcRn and Design of IgG1 Variants with Improved Binding to the Fcgamma R. J. Biol. Chem. (2001) 276:6591-604. doi: 10.1074/jbc.M009483200

15. Brekke $\mathrm{OH}$, Michaelsen TE, Sandlie I. The structural requirements for complement activation by IgG: does it hinge on the hinge? Immunol Today. (1995) 16:85-90. doi: 10.1016/0167-5699(95)80094-8

16. Idusogie EE, Presta LG, Gazzano-Santoro H, Totpal K, Wong PY, Ultsch $\mathrm{M}$, et al. Mapping of the $\mathrm{Clq}$ binding site on rituxan, a chimeric antibody with a human IgG1 Fc. J Immunol. (2000) 164:4178-84. doi: 10.4049/jimmunol.164.8.4178

17. Morgan A, Jones ND, Nesbitt AM, Chaplin L, Bodmer MW, Emtage JS. The $\mathrm{N}$-terminal end of the $\mathrm{CH} 2$ domain of chimeric human IgG1 anti-HLA-DR is necessary for $\mathrm{Clq}$, Fc gamma RI and Fc gamma RIII binding. Immunology. (1995) 86:319-24.

18. West AP Jr, Bjorkman PJ. Crystal structure and immunoglobulin G binding properties of the human major histocompatibility complex-related Fc receptor(,). Biochemistry. (2000) 39:9698-708. doi: 10.1021/bi000749m 
19. James LC, Keeble AH, Khan Z, Rhodes DA, Trowsdale J. Structural basis for PRYSPRY-mediated tripartite motif (TRIM) protein function. Proc Natl Acad Sci USA. (2007) 104:6200-5. doi: 10.1073/pnas.0609174104

20. Krapp S, Mimura Y, Jefferis R, Huber R, Sondermann P. Structural analysis of human IgG-Fc glycoforms reveals a correlation between glycosylation and structural integrity. J Mol Biol. (2003) 325:979-89. doi: 10.1016/S0022-2836(02)01250-0

21. Okazaki A, Shoji-Hosaka E, Nakamura K, Wakitani M, Uchida K, Kakita S, et al. Fucose depletion from human IgG1 oligosaccharide enhances binding enthalpy and association rate between IgG1 and FcgammaRIIIa. J Mol Biol. (2004) 336:1239-49. doi: 10.1016/j.jmb.2004.01.007

22. Ferrara C, Grau S, Jager C, Sondermann P, Brunker P, Waldhauer I, et al. Unique carbohydrate-carbohydrate interactions are required for high affinity binding between FcgammaRIII and antibodies lacking core fucose. Proc Natl Acad Sci USA. (2011) 108:12669-74. doi: 10.1073/pnas.1108455108

23. Ferrara C, Stuart F, Sondermann P, Brunker P, Umana P. The carbohydrate at FcgammaRIIIa Asn-162. An element required for high affinity binding to non-fucosylated IgG glycoforms. J Biol Chem. (2006) 281:5032-6. doi: 10.1074/jbc.M510171200

24. Shields RL, Lai J, Keck R, O’Connell LY, Hong K, Meng YG, et al. Lack of fucose on human IgG1 N-linked oligosaccharide improves binding to human Fcgamma RIII and antibody-dependent cellular toxicity. J Biol Chem. (2002) 277:26733-40. doi: 10.1074/jbc.M202069200

25. Kaneko Y, Nimmerjahn F, Ravetch JV. Anti-inflammatory activity of immunoglobulin G resulting from Fc sialylation. Science. (2006) 313:670-3. doi: $10.1126 /$ science. 1129594

26. van de Geijn FE, Wuhrer M, Selman MH, Willemsen SP, de Man YA, Deelder AM, et al. Immunoglobulin G galactosylation and sialylation are associated with pregnancy-induced improvement of rheumatoid arthritis and the postpartum flare: results from a large prospective cohort study. Arthritis Res Ther. (2009) 11:R193. doi: 10.1186/ar2892

27. Nakajima S, Iijima H, Shinzaki S, Egawa S, Inoue T, Mukai A, et al. Functional analysis of agalactosyl IgG in inflammatory bowel disease patients. Inflamm Bowel Dis. (2011) 17:927-936. doi: 10.1002/ibd.21459

28. Dube R, Rook GA, Steele J, Brealey R, Dwek R, Rademacher T, et al. Agalactosyl IgG in inflammatory bowel disease: correlation with C-reactive protein. Gut. (1990) 31:431-4. doi: 10.1136/gut.31.4.431

29. Ogata S, Shimizu C, Franco A, Touma R, Kanegaye JT, Choudhury BP, et al. Treatment response in Kawasaki disease is associated with sialylation levels of endogenous but not therapeutic intravenous immunoglobulin G. PLoS ONE. (2013) 8:e81448. doi: 10.1371/journal.pone.0081448

30. Nagelkerke SQ, Dekkers G, Kustiawan I, van de Bovenkamp FS, Geissler J, Plomp R, et al. Inhibition of FcgammaR-mediated phagocytosis by IVIg is independent of IgG-Fc sialylation and FcgammaRIIb in human macrophages. Blood. (2014) 124:3709-18. doi: 10.1182/blood-2014-05-576835

31. Bayry J, Bansal K, Kazatchkine MD, Kaveri SV. DC-SIGN and alpha2,6sialylated IgG Fc interaction is dispensable for the anti-inflammatory activity of IVIg on human dendritic cells. Proc Natl Acad Sci USA. (2009) 106:E24; author reply E25. doi: 10.1073/pnas.0900016106

32. Kasermann F, Boerema DJ, Ruegsegger M, Hofmann A, Wymann S, Zuercher $\mathrm{AW}$, et al. Analysis and functional consequences of increased Fab-sialylation of intravenous immunoglobulin (IVIG) after lectin fractionation. PLOS ONE. (2012) 7:e37243. doi: 10.1371/journal.pone.0037243

33. Ravetch JV, Bolland S. IgG Fc receptors. Annu Rev Immunol. (2001) 19:27590. doi: 10.1146/annurev.immunol.19.1.275

34. Selvaraj P, Carpen O, Hibbs ML, Springer TA. Natural killer cell and granulocyte Fc gamma receptor III (CD16) differ in membrane anchor and signal transduction. J Immunol. (1989) 143:3283-8.

35. Su K, Li X, Edberg JC, Wu J, Ferguson P, Kimberly RP. A promoter haplotype of the immunoreceptor tyrosine-based inhibitory motif-bearing FcgammaRIIb alters receptor expression and associates with autoimmunity. II. Differential binding of GATA4 and Yin-Yang1 transcription factors and correlated receptor expression and function. J Immunol. (2004) 172:7192-9. doi: 10.4049/jimmunol.172.11.7192

36. Su K, Wu J, Edberg JC, Li X, Ferguson P, Cooper GS, et al. A promoter haplotype of the immunoreceptor tyrosine-based inhibitory motif-bearing FcgammaRIIb alters receptor expression and associates with autoimmunity. I. Regulatory FCGR2B polymorphisms and their association with systemic lupus erythematosus. J Immunol. (2004) 172:7186-91. doi: 10.4049/jimmunol.172.11.7186

37. Morphis LG, Gitlin D. Maturation of the maternofoetal transport system for human gamma-globulin in the mouse. Nature. (1970) 228:573. doi: $10.1038 / 228573 \mathrm{a} 0$

38. Brambell FW. The transmission of immunity from mother to young and the catabolism of immunoglobulins. Lancet. (1966) 2:1087-93. doi: 10.1016/S0140-6736(66)92190-8

39. Kandil E, Egashira M, Miyoshi O, Niikawa N, Ishibashi T, Kasahara M. The human gene encoding the heavy chain of the major histocompatibility complex class I-like Fc receptor (FCGRT) maps to 19q13.3. Cytogenet Cell Genet. (1996) 73:97-8. doi: 10.1159/000134316

40. Roopenian DC, Christianson GJ, Sproule TJ, Brown AC, Akilesh S, Jung N, et al. The MHC Class I-Like IgG receptor controls perinatal IgG Transport, IgG Homeostasis, and Fate of IgG-Fc-Coupled Drugs. J Immunol. (2003) 170:3528-33. doi: 10.4049/jimmunol.170.7.3528

41. Roopenian DC, Akilesh S. FcRn: the neonatal Fc receptor comes of age. Nat Rev Immunol. (2007) 7:715. doi: 10.1038/nri2155

42. Raghavan M, Bonagura VR, Morrison SL, Bjorkman PJ. Analysis of the $\mathrm{pH}$ dependence of the neonatal Fc receptor/immunoglobulin $\mathrm{G}$ interaction using antibody and receptor variants. Biochemistry. (1995) 34:14649-57. doi: 10.1021/bi00045a005

43. Petkova SB, Akilesh S, Sproule TJ, Christianson GJ, Al Khabbaz H, Brown AC, et al. Enhanced half-life of genetically engineered human IgG1 antibodies in a humanized FcRn mouse model: potential application in humorally mediated autoimmune disease. Int Immunol. (2006) 18:1759-69. doi: 10.1093/intimm/dxl110

44. Venables PJ. Sjogren's syndrome. Best Pract Res Clin Rheumatol. (2004) 18:313-29. doi: 10.1016/j.berh.2004.02.010

45. Keeble AH, Khan Z, Forster A, James LC. TRIM21 is an IgG receptor that is structurally, thermodynamically, kinetically conserved. Proc Natl Acad Sci USA. (2008) 105:6045-50. doi: 10.1073/pnas.0800159105

46. Mallery DL, McEwan WA, Bidgood SR, Towers GJ, Johnson CM, James LC. Antibodies mediate intracellular immunity through tripartite motifcontaining 21 (TRIM21). Proc Natl Acad Sci USA. (2010) 107:19985-90. doi: $10.1073 /$ pnas.1014074107

47. Ng PML, Kaliaperumal N, Lee CY, Chin WJ, Tan HC, Au VB, et al. Enhancing antigen cross-presentation in human monocyte-derived dendritic cells by recruiting the intracellular Fc receptor TRIM21. J Immunol. (2019) 202:2307-19. doi: 10.4049/jimmunol.1800462

48. Oke V, Vassilaki I, Espinosa A, Strandberg L, Kuchroo VK, Nyberg F, et al. High Ro52 expression in spontaneous and UV-induced cutaneous inflammation. J Invest Dermatol. (2009) 129:2000-10. doi: $10.1038 /$ jid.2008.453

49. Wilson TJ, Fuchs A, Colonna M. Cutting edge: human FcRL4 and FcRL5 are receptors for IgA and IgG. J Immunol. (2012) 188:4741-5. doi: 10.4049/jimmunol.1102651

50. Franco A, Damdinsuren B, Ise T, Dement-Brown J, Li H, Nagata S, et al. Human Fc receptor-like 5 binds intact IgG via mechanisms distinct from those of Fc receptors. J Immunol. (2013) 190:5739-46. doi: 10.4049/jimmunol.1202860

51. Haga CL, Ehrhardt GR, Boohaker RJ, Davis RS, Cooper MD. Fc receptorlike 5 inhibits B cell activation via SHP-1 tyrosine phosphatase recruitment. Proc Natl Acad Sci USA. (2007) 104:9770-5. doi: 10.1073/pnas.07033 54104

52. Strang CJ, Siegel RC, Phillips ML, Poon PH, Schumaker VN. Ultrastructure of the first component of human complement: electron microscopy of the crosslinked complex. Proc Natl Acad Sci USA. (1982) 79:586-90. doi: $10.1073 /$ pnas.79.2.586

53. Hughes-Jones NC, Gardner B. Reaction between the isolated globular sub-units of the complement component $\mathrm{Clq}$ and $\mathrm{IgG}$-complexes. Mol Immunol. (1979) 16:697-701. doi: 10.1016/0161-5890(79) 90010-5

54. Diebolder CA, Beurskens FJ, de Jong RN, Koning RI, Strumane K, Lindorfer MA, et al. Complement is activated by IgG hexamers assembled at the cell surface. Science. (2014) 343:1260-3. doi: 10.1126/science.12 48943 
55. Feinstein A, Richardson N, Taussig MI. Immunoglobulin flexibility in complement activation. Immunol Today. (1986) 7:169-74. doi: 10.1016/0167-5699(86)90168-4

56. Wang G, de Jong RN, van den Bremer ET, Beurskens FJ, Labrijn AF, Ugurlar D, et al. Molecular basis of assembly and activation of complement component C1 in complex with immunoglobulin G1 and antigen. Mol Cell. (2016) 63:135-45. doi: 10.1016/j.molcel.2016.05.016

57. Flexner S. On the promoting influence of heated tumor emulsions on tumor growth. Soc Exp Biol Med. (1906) 4:156-7. doi: 10.3181/00379727-4-109

58. Kaliss N. Acceptance of tumor homografts by mice injected with antiserum. II. Effect of time of injection. Proc Soc Exp Biol Med. (1956) 91:432-7. doi: 10.3181/00379727-91-22285

59. Kaliss N, Molomut N. The effect of prior injections of tissue antiserums on the survival of cancer homoiografts in mice. Cancer Res. (1952) 12:110-2.

60. Kaliss N, Molomut N, Harriss JL, Gault SD. Effect of previously injected immune serum and tissue on the survival of tumor grafts in mice. J Natl Cancer Inst. (1953) 13:847-50.

61. Kaliss N. Immunological enhancement of tumor homografts in mice: a review. Cancer Res. (1958) 18:992-1003.

62. Kaliss N, Kandutsch AA. Acceptance of tumor homografts by mice injected with antiserum. I. Activity of serum fractions. Proc Soc Exp Biol Med. (1956) 91:118-21. doi: 10.3181/00379727-91-22185

63. Braslawsky GR, Yaackubowicz M, Frensdorff A, Witz IP. Receptors for immune complexes on cells within a non-lymphoid murine tumor. $J$ Immunol. (1976) 116:1571-8.

64. Clerici M, Clerici E, Shearer GM. The tumor enhancement phenomenon: reinterpretation from a Th1/Th2 perspective. J Natl Cancer Inst. (1996) 88:461-2. doi: 10.1093/jnci/88.7.461

65. Salama A, Kiefel V, Mueller-Eckhardt C. Effect of IgG anti-Rho(D) in adult patients with chronic autoimmune thrombocytopenia. Am J Hematol. (1986) 22:241-50. doi: 10.1002/ajh.2830220304

66. Becker T, Kuenzlen E, Salama A, Mertens R, Kiefel V, Weiss H, et al. Treatment of childhood idiopathic thrombocytopenic purpura with Rhesus antibodies (anti-D). Eur J Pediatr. (1986) 145:166-9. doi: 10.1007/BF00446055

67. Salama A, Kiefel V, Amberg R, Mueller-Eckhardt C. Treatment of autoimmune thrombocytopenic purpura with rhesus antibodies (antiRh0(D). Blut. (1984) 49:29-35. doi: 10.1007/BF00320381

68. Bussel JB, Graziano JN, Kimberly RP, Pahwa S, Aledort LM. Intravenous anti-D treatment of immune thrombocytopenic purpura: analysis of efficacy, toxicity, and mechanism of effect. Blood. (1991) 77:1884-93. doi: 10.1182/blood.V77.9.1884.1884

69. Oksenhendler E, Bierling P, Brossard Y, Schenmetzler C, Girard PM, Seligmann $\mathrm{M}$, et al. Anti-RH immunoglobulin therapy for human immunodeficiency virus-related immune thrombocytopenic purpura. Blood. (1988) 71:1499-502. doi: 10.1182/blood.V71.5.1499.1499

70. Lu J, Mold C, Du Clos TW, Sun PD. Pentraxins and Fc receptormediated immune responses. Front Immunol. (2018) 9:2607. doi: 10.3389/fimmu.2018.02607

71. Du Clos TW. Pentraxins: structure, function, and role in inflammation. ISRN Inflamm. (2013) 2013:379040. doi: 10.1155/2013/379040

72. Cox N, Pilling D, Gomer RH. Serum amyloid P: a systemic regulator of the innate immune response. J Leukoc Biol. (2014) 96:739-743. doi: 10.1189/jlb.1MR0114-068R

73. Niknami M, Wang, MX, Nguyen T, Pollard JD. Beneficial effect of a multimerized immunoglobulin Fc in an animal model of inflammatory neuropathy (experimental autoimmune neuritis). J Peripher Nerv System. (2013) 18:141-52. doi: 10.1111/jns5.12022

74. Thiruppathi M, Sheng JR, Li L, Prabhakar BS, Meriggioli MN. Recombinant IgG2a Fc (M045) multimers effectively suppress experimental autoimmune myasthenia gravis. J Autoimmun. (2014) 52:64-73. doi: 10.1016/j.jaut.2013.12.014

75. Zhou H, Olsen H, So E, Merigeon E, Rybin D, Owens J, et al. A fully recombinant human IgG1 Fc multimer (GL-2045) inhibits complementmediated cytotoxicity and induces iC3b. Blood Adv. (2017) 1:504-15. doi: 10.1182/bloodadvances.2016001917

76. Zhang X, Owens J, Olsen HS, So E, Burch E, McCroskey MC, et al. A recombinant human IgG1 Fc multimer designed to mimic the active fraction of IVIG in autoimmunity. JCI Insight. (2019) 4:e121905 doi: 10.1172/jci.insight.121905

77. Mekhaiel DN, Czajkowsky DM, Andersen JT, Shi J, El-Faham M, Doenhoff $\mathrm{M}$, et al. Polymeric human Fc-fusion proteins with modified effector functions. Sci Rep. (2011) 1:124. doi: 10.1038/srep00124

78. Sorensen V, Sundvold V, Michaelsen TE, Sandlie I. Polymerization of IgA and IgM: roles of Cys309/Cys414 and the secretory tailpiece. J Immunol. (1999) 162:3448-55.

79. Ghumra A, Semblat JP, McIntosh RS, Raza A, Rasmussen IB, Braathen $\mathrm{R}$, et al. Identification of residues in the Cmu4 domain of polymeric IgM essential for interaction with Plasmodium falciparum erythrocyte membrane protein 1 (PfEMP1). J Immunol. (2008) 181:1988-2000. doi: 10.4049/jimmunol.181.3.1988

80. Qureshi OS, Rowley TF, Junker F, Peters SJ, Crilly S, Compson J, et al. Multivalent Fcgamma-receptor engagement by a hexameric Fc-fusion protein triggers Fcgamma-receptor internalisation and modulation of Fcgamma-receptor functions. Sci Rep. (2017) 7:17049. doi: 10.1038/s41598-017-17255-8

81. Lewis BJB, Ville J, Blacquiere M, Cen S, Spirig R, Zuercher AW, et al. Using the $\mathrm{K} / \mathrm{BxN}$ mouse model of endogenous, chronic, rheumatoid arthritis for the evaluation of potential immunoglobulin-based therapeutic agents, including IVIg and Fc-muTP-L309C, a recombinant IgG1 Fc hexamer. BMC Immunol. (2019) 20:44. doi: 10.1186/s12865-0190328-6

82. Ortiz DF, Lansing JC, Rutitzky L, Kurtagic E, Prod'homme T, Choudhury A, et al. Elucidating the interplay between IgG-Fc valency and FcgammaR activation for the design of immune complex inhibitors. Sci Transl Med. (2016) 8:365ra158. doi: 10.1126/scitranslmed. aaf9418

83. Ghielmetti M, Bellis M, Spycher MO, Miescher S, Vergeres G. Gene expression profiling of the effects of intravenous immunoglobulin in human whole blood. Mol Immunol. (2006) 43:939-49. doi: 10.1016/j.molimm.2005.06.024

84. Andresen I, Kovarik JM, Spycher M, Bolli R. Product equivalence study comparing the tolerability, pharmacokinetics, and pharmacodynamics of various human immunoglobulin-G formulations. J Clin Pharmacol. (2000) 40:722-30. doi: 10.1177/00912700022009477

85. Kroez M, Kanzy EJ, Gronski P, Dickneite G. Hypotension with intravenous immunoglobulin therapy: importance of $\mathrm{pH}$ and dimer formation. Biologicals. (2003) 31:277-86. doi: 10.1016/j.biologicals.2003. 09.001

86. Spirig R, Campbell IK, Koernig S, Chen CG, Lewis BJB, Butcher R, et al. rIgG1 Fc hexamer inhibits antibody-mediated autoimmune disease via effects on complement and FcgammaRs. J Immunol. (2018) 200:2542-53. doi: 10.4049/jimmunol.1701171

87. Akilesh S, Petkova S, Sproule TJ, Shaffer DJ, Christianson GJ, Roopenian D. The MHC class I-like Fc receptor promotes humorally mediated autoimmune disease. J Clin Invest. (2004) 113:1328-33. doi: 10.1172/JCI18838

88. Waldmann TA, Strober W. Metabolism of immunoglobulins. Prog Allergy. (1969) 13:1-10. doi: 10.1159/000385919

89. Ghetie V, Hubbard JG, Kim JK, Tsen MF, Lee Y, Ward ES. Abnormally short serum half-lives of IgG in beta 2-microglobulin-deficient mice. Eur J Immunol. (1996) 26:690-6. doi: 10.1002/eji.1830260327

90. Israel EJ, Wilsker DF, Hayes KC, Schoenfeld D, Simister NE. Increased clearance of IgG in mice that lack beta 2-microglobulin: possible protective role of FcRn. Immunology. (1996) 89:573-8. doi: 10.1046/j.1365-2567.1996.d01-775.x

91. Junghans RP. Finally! The Brambell receptor (FcRB). Mediator of transmission of immunity and protection from catabolism for IgG. Immunol Res. (1997) 16:29-57. doi: 10.1007/BF02786322

92. Masson PL. Elimination of infectious antigens and increase of $\operatorname{IgG}$ catabolism as possible modes of action of IVIg. J Autoimmun. (1993) 6:6839. doi: 10.1006/jaut.1993.1057

93. Bleeker WK, Teeling JL, Hack CE. Accelerated autoantibody clearance by intravenous immunoglobulin therapy: studies in experimental models to determine the magnitude and time course of the effect. Blood. (2001) 98:3136-42. doi: 10.1182/blood.V98.10.3136 
94. Yu Z, Lennon VA. Mechanism of intravenous immune globulin therapy in antibody-mediated autoimmune diseases. N Engl J Med. (1999) 340:227-8. doi: 10.1056/NEJM199901213400311

95. Li N, Zhao M, Hilario-Vargas J, Prisayanh P, Warren S, Diaz LA, et al. Complete FcRn dependence for intravenous Ig therapy in autoimmune skin blistering diseases. J Clin Invest. (2005) 115:3440-50. doi: 10.1172/JCI24394

96. Hansen RJ, Balthasar JP. Effects of intravenous immunoglobulin on platelet count and antiplatelet antibody disposition in a rat model of immune thrombocytopenia. Blood. (2002) 100:2087-93. doi: 10.1182/blood.V100.6.2087

97. Bolland S, Ravetch JV. Inhibitory pathways triggered by ITIM-containing receptors. Adv Immunol. (1999) 72:149-77. doi: 10.1016/S0065-2776(08)60019-X

98. Ravetch JV, Lanier LL. Immune inhibitory receptors. Science. (2000) 290:849. doi: 10.1126/science.290.5489.84

99. Pearse RN, Kawabe T, Bolland S, Guinamard R, Kurosaki T, Ravetch JV. SHIP recruitment attenuates Fc gamma RIIB-induced B cell apoptosis. Immunity. (1999) 10:753-60. doi: 10.1016/S1074-7613(00)80074-6

100. Tzeng SJ, Bolland S, Inabe K, Kurosaki T, Pierce SK. The B cell inhibitory Fc receptor triggers apoptosis by a novel c-Abl family kinase-dependent pathway. J Biol Chem. (2005) 280:35247-54. doi: 10.1074/jbc.M5053 08200

101. Bruhns P, Samuelsson A, Pollard JW, Ravetch JV. Colony-stimulating factor-1-dependent macrophages are responsible for IVIG protection in antibody-induced autoimmune disease. Immunity. (2003) 18:573-81. doi: 10.1016/S1074-7613(03)00080-3

102. Samuelsson A, Towers TL, Ravetch JV. Anti-inflammatory activity of IVIG mediated through the inhibitory Fc receptor. Science. (2001) 291:484-6. doi: 10.1126/science.291.5503.484

103. Park-Min KH, Serbina NV, Yang W, Ma X, Krystal G, Neel BG, et al. FcgammaRIII-dependent inhibition of interferon-gamma responses mediates suppressive effects of intravenous immune globulin. Immunity. (2007) 26:67-78. doi: 10.1016/j.immuni.2006.11.010

104. Miles SA, Conrad SM, Alves RG, Jeronimo SM, Mosser DM. A role for IgG immune complexes during infection with the intracellular pathogen Leishmania. J Exp Med. (2005) 201:747-54. doi: 10.1084/jem.20041470

105. Suhrbier A, La Linn. M. Suppression of antiviral responses by antibodydependent enhancement of macrophage infection. Trends Immunol. (2003) 24:165-8. doi: 10.1016/S1471-4906(03)00065-6

106. Gerber JS, Mosser DM. Reversing lipopolysaccharide toxicity by ligating the macrophage Fc gamma receptors. J Immunol. (2001) 166:6861-8. doi: 10.4049/jimmunol.166.11.6861

107. Bayry J, Mouthon L, Kaveri SV. Intravenous immunoglobulin expands regulatory $\mathrm{T}$ cells in autoimmune rheumatic disease. J Rheumatol. (2012) 39:450-1. doi: 10.3899/jrheum.111123

108. Tsurikisawa N, Saito H, Oshikata C, Tsuburai T, Akiyama K. High-dose intravenous immunoglobulin treatment increases regulatory $\mathrm{T}$ cells in patients with eosinophilic granulomatosis with polyangiitis. J Rheumatol. (2012) 39:1019-25. doi: 10.3899/jrheum.110981

109. Kessel A, Ammuri H, Peri R, Pavlotzky ER, Blank M, Shoenfeld Y, et al. Intravenous immunoglobulin therapy affects $\mathrm{T}$ regulatory cells by increasing their suppressive function. J Immunol. (2007) 179:5571-5. doi: 10.4049/jimmunol.179.8.5571

110. De Groot AS, Moise L, McMurry JA, Wambre E, Van Overtvelt $\mathrm{L}$, Moingeon $\mathrm{P}$, et al. Activation of natural regulatory $\mathrm{T}$ cells by IgG Fc-derived peptide “Tregitopes". Blood. (2008) 112:3303-11. doi: 10.1182/blood-2008-02-138073

111. Cousens LP, Tassone R, Mazer BD, Ramachandiran V, Scott DW, De Groot. A. S. Tregitope update: mechanism of action parallels IVIg. Autoimmun Rev. (2013) 12:436-43. doi: 10.1016/j.autrev.2012.08.017

112. Burns JC, Song Y, Bujold M, Shimizu C, Kanegaye JT, Tremoulet AH, et al. Immune-monitoring in Kawasaki disease patients treated with infliximab and intravenous immunoglobulin. Clin Exp Immunol. (2013) 174:337-44. doi: $10.1111 /$ cei.12182

113. Massoud AH, Guay J, Shalaby KH, Bjur E, Ablona A, Chan D, et al. Intravenous immunoglobulin attenuates airway inflammation through induction of forkhead box protein 3-positive regulatory T cells. J Allergy Clin Immunol. (2012) 129:1656-65 e1653. doi: 10.1016/j.jaci.2012.02.050
114. Yamamoto M, Kobayashi K, Ishikawa Y, Nakata K, Funada Y, Kotani $\mathrm{Y}$, et al. The inhibitory effects of intravenous administration of rabbit immunoglobulin $\mathrm{G}$ on airway inflammation are dependent upon Fcgamma receptor IIb on $\mathrm{CD} 11 \mathrm{c}(+)$ dendritic cells in a murine model. Clin Exp Immunol. (2010) 162:315-24. doi: 10.1111/j.1365-2249.2010.04243.x

115. Trinath J, Hegde P, Sharma M, Maddur MS, Rabin M, Vallat JM, et al. Intravenous immunoglobulin expands regulatory $\mathrm{T}$ cells via induction of cyclooxygenase-2-dependent prostaglandin E2 in human dendritic cells. Blood. (2013) 122:1419-27. doi: 10.1182/blood-2012-11-468264

116. Takahara M, Kang K, Liu L, Yoshida Y, McCormick TS, Cooper KD. iC3b arrests monocytic cell differentiation into CD1c-expressing dendritic cell precursors: a mechanism for transiently decreased dendritic cells in vivo after human skin injury by ultraviolet B. J Invest Dermatol. (2003) 120:802-9. doi: 10.1046/j.1523-1747.2003.12136.x

117. Sohn JH, Bora PS, Suk HJ, Molina H, Kaplan HJ, Bora NS. Tolerance is dependent on complement $\mathrm{C} 3$ fragment $\mathrm{iC} 3 \mathrm{~b}$ binding to antigen-presenting cells. Nat Med. (2003) 9:206-12. doi: 10.1038/nm814

118. Verbovetski I, Bychkov H, Trahtemberg U, Shapira I, Hareuveni M, BenTal O, et al. Opsonization of apoptotic cells by autologous iC3b facilitates clearance by immature dendritic cells, down-regulates DR and CD86, and up-regulates CC chemokine receptor 7. J Exp Med. (2002) 196:1553-61. doi: 10.1084 /jem. 20020263

119. Takizawa F, Tsuji S, Nagasawa S. Enhancement of macrophage phagocytosis upon iC3b deposition on apoptotic cells. FEBS Lett. (1996) 397:269-72. doi: 10.1016/S0014-5793(96)01197-0

120. Micklem KJ, Sim RB. Isolation of complement-fragment-iC3b-binding proteins by affinity chromatography. The identification of p150,95 as an iC3b-binding protein. Biochem J. (1985) 231:233-6. doi: 10.1042/bj2310233

121. Albert ML. Death-defying immunity: do apoptotic cells influence antigen processing and presentation? Nat Rev Immunol. (2004) 4:223-31. doi: $10.1038 /$ nri1 1308

122. Davies KA, Erlendsson K, Beynon HL, Peters AM, Steinsson K, Valdimarsson $\mathrm{H}$, et al. Splenic uptake of immune complexes in man is complementdependent. J Immunol. (1993) 151:3866-73.

123. Bruhns P, Iannascoli B, England P, Mancardi DA, Fernandez N, Jorieux $S$, et al. Specificity and affinity of human Fcgamma receptors and their polymorphic variants for human IgG subclasses. Blood. (2009) 113:3716-25. doi: 10.1182/blood-2008-09-179754

124. Lux A, Yu X, Scanlan CN, Nimmerjahn F. Impact of Immune Complex Size and Glycosylation on IgG Binding to Human Fc $\gamma$ Rs. J Immunol. (2013) 190:4315-23. doi: 10.4049/jimmunol.1200501

125. Nash JT, Taylor PR, Botto M, Norsworthy PJ, Davies KA, Walport MJ. Immune complex processing in $\mathrm{Clq}$-deficient mice. Clin Exp Immunol. (2001) 123:196-202. doi: 10.1046/j.1365-2249.2001.01459.x

126. Vollmer J, Tluk S, Schmitz C, Hamm S, Jurk M, Forsbach A, et al. Immune stimulation mediated by autoantigen binding sites within small nuclear RNAs involves Toll-like receptors 7 and 8. J Exp Med. (2005) 202:1575-85. doi: 10.1084/jem.20051696

127. Wang JP, Asher DR, Chan M, Kurt-Jones EA, Finberg RW. Cutting Edge: antibody-mediated TLR7-dependent recognition of viral RNA. J Immunol. (2007) 178:3363-7. doi: 10.4049/jimmunol.178.6.3363

128. Bournazos S, Ravetch JV. Fcgamma receptor pathways during active and passive immunization. Immunol Rev. (2015) 268:88-103. doi: 10.1111/imr.12343

129. Roghanian A, Teige I, Martensson L, Cox KL, Kovacek M, Ljungars A, et al. Antagonistic human FcgammaRIIB (CD32B) antibodies have anti-tumor activity and overcome resistance to antibody therapy in vivo. Cancer Cell. (2015) 27:473-88. doi: 10.1016/j.ccell.2015.03.005

130. Rieth N, Carle A, Muller MA, ter Meer D, Direnberger C, Pohl T, et al. Characterization of SM201, an anti-hFcgammaRIIB antibody not interfering with ligand binding that mediates immune complex dependent inhibition of B cells. Immunol Lett. (2014) 160:145-50. doi: 10.1016/j.imlet.2014. 01.012

131. Ericson SG, Coleman KD, Wardwell K, Baker S, Fanger MW, Guyre PM, et al. Monoclonal antibody 197 (anti-Fc gamma RI) infusion in a patient with immune thrombocytopenia purpura (ITP) results in down-modulation of Fc gamma RI on circulating monocytes. Br J Haematol. (1996) 92:718-24. doi: 10.1046/j.1365-2141.1996.393931.x 
132. Clarkson SB, Bussel JB, Kimberly RP, Valinsky JE, Nachman RL, Unkeless JC. Treatment of refractory immune thrombocytopenic purpura with an anti-Fc gamma-receptor antibody. N Engl J Med. (1986) 314:1236-9. doi: 10.1056/NEJM198605083141907

133. Flaherty MM, MacLachlan TK, Troutt M, Magee T, Tuaillon N, Johnson S, et al. Nonclinical evaluation of GMA161-an antihuman CD16 (FcgammaRIII) monoclonal antibody for treatment of autoimmune disorders in CD16 transgenic mice. Toxicol Sci. (2012) 125:299-309. doi: 10.1093/toxsci/ kfr278

134. Ling LE, Hillson JL, Tiessen RG, Bosje T, van Iersel MP, Nix DJ, et al. M281, an Anti-FcRn antibody: Pharmacodynamics, Pharmacokinetics, and safety across the full range of $\operatorname{IgG}$ reduction in a first-inhuman study. Clin Pharmacol Ther. (2019) 105:1031-9. doi: 10.1002/ cpt.1276

135. Kiessling P, Lledo-Garcia R, Watanabe S, Langdon G, Tran D, Bari $\mathrm{M}$, et al. The FcRn inhibitor rozanolixizumab reduces human serum IgG concentration: a randomized phase 1 study. Sci Transl Med. (2017) 9:eaan1208. doi: 10.1126/scitranslmed.an1208
Conflict of Interest: SS is a cofounder, paid consultant, stockholder, and has received research support from Gliknik Inc., a biotechnology company. His laboratory has received research support from Pfizer Inc. through a sponsored research agreement. He also receives royalties from intellectual property related to B7-H1(PD-L1): PD-1 licensed by the Mayo Clinic College of Medicine to third parties. He sits on the scientific advisory board of Virion Inc.

The remaining authors declare that the research was conducted in the absence of any commercial or financial relationships that could be construed as a potential conflict of interest.

Copyright $\odot 2020$ Fitzpatrick, Wang and Strome. This is an open-access article distributed under the terms of the Creative Commons Attribution License (CC BY). The use, distribution or reproduction in other forums is permitted, provided the original author(s) and the copyright owner(s) are credited and that the original publication in this journal is cited, in accordance with accepted academic practice. No use, distribution or reproduction is permitted which does not comply with these terms. 